Original Article

\title{
Composition and spatio-temporal dynamics of aquatic bird community in humid areas of Alto Parana Atlantic Forest
}

\author{
Composição e dinâmica espaço-temporal da comunidade de aves aquáticas em áreas \\ úmidas da Floresta Atlântica do Alto Paraná
}

\author{
B. M. Lima ${ }^{a}$ (D) J. Ragusa-Netto ${ }^{\mathrm{b}}$ (1), R. J. Donatellic (D) and S. R. Posso ${ }^{\mathrm{d} *}$ (1) \\ aUniversidade Federal de Mato Grosso do Sul - UFMS, Instituto de Biociências - INBIO, Programa de Pós-graduação em Biologia Animal, Campo \\ Grande, MS, Brasil \\ bUniversidade Federal do Mato Grosso do Sul - UFMS, Departamento de Ciências Naturais, Três Lagoas, MS, Brasil \\ cUniversidade Estadual Paulista - UNESP, Departamento de Ciências Biológicas, Laboratório de Ornitologia, Bauru, SP, Brasil \\ dUniversidade Federal de Mato Grosso do Sul - UFMS, Laboratório de Ecologia, Sistemática e Conservação das Aves Neotropicais - LESCAN, Três \\ Lagoas, MS, Brasil
}

\begin{abstract}
The northwestern portion of the Upper Paraná Atlantic Forest ecoregion is one of the most disturbed and fragmented areas in the Atlantic Forest, and little is known about the local avifauna. In this study, we have described the composition and diversity of the aquatic avifauna of this region and analyzed the patterns of similarity with respect to the seasonal as well as spatial distribution. We used the line transect sampling technique in six distinct humid areas (including lentic and lotic water bodies) during the dry and rainy seasons of 2012 and 2013. A total of 52 species of waterfowl were recorded. The species richness of the studied areas was surprisingly distinct; only seven waterfowl species, namely Cairina moschata (Linnaeus, 1758), Tigrisoma lineatum (Boddaert, 1783), Rosthramus sociabilis (Vieillot, 1817), Aramus guarauna (Linnaeus, 1766), Vanellus chilensis (Molina, 1782), Jacana jacana (Linnaeus, 1766), and Arundinicola leucocephala (Linnaeus, 1764), were common to these six studied areas. This indicated that the other bird species that were observed might be habitat selective. Moreover, the analysis of the composition of birds in the two seasons (dry and rainy) combined with their spatial distributions showed significant dissimilarities between the areas with lotic (river and constructed wetland) and lentic (lagoons) characteristics. Nevertheless, despite the small extent and low total richness of the entire study area, it was found to be home to $1 / 3$ of all freshwater aquatic birds documented in the state of São Paulo, with the record of 5 migratory species and 11 new species added to the northwest of the state. The heterogeneity of local aquatic environments, habitat selection combined with seasonality, and the absence of other humid locations in the surroundings can explain the diversity and distribution of these birds in the water bodies of this uninvestigated Atlantic Forest ecoregion.
\end{abstract}

Keywords: wet areas, bird assembly, waterfowl, environment heterogeneity.

\section{Resumo}

A porção noroeste da ecorregião Floresta Atlântica do Alto Paraná é uma das mais alteradas e fragmentadas da Mata Atlântica, da qual pouco se sabe sobre a avifauna local. Nosso objetivo foi descrever a diversidade e composição da avifauna aquática, bem como analisar os padrões de similaridade quanto a distribuição temporal e espacial destas aves nesta ecorregião. Utilizamos a transecção linear para amostragem em seis áreas úmidas (corpos d'água lênticos e lóticos), nos períodos de seca e chuva entre 2012 e 2013. Registramos 52 espécies de aves aquáticas e as riquezas das áreas mostraram-se distintas, pois apenas Cairina moschata (Linnaeus, 1758), Tigrisoma lineatum (Boddaert, 1783), Rosthramus sociabilis (Vieillot, 1817), Aramus guarauna (Linnaeus, 1766), Vanellus chilensis (Molina, 1782), Jacana jacana (Linnaeus, 1766), and Arundinicola leucocephala (Linnaeus, 1764) foram comuns às seis áreas, o que indica seleção de habitat. Quando analisada a composição das aves nos dois períodos aliada à distribuição espacial, encontramos dissimilaridades temporais acentuadas entre os ambientes com características lóticas (rio e aterro) e lênticas (lagoas). Isto mostra que, além das diferentes épocas sazonais, é necessário analisar separadamente os diferentes tipos de áreas úmidas. Por fim, apesar da extensão pequena e baixa riqueza total, a área amostrada abrigou $1 / 3$ das aves aquáticas de água doce para o estado de São Paulo, cinco espécies migratórias e 11 novas espécies para o noroeste do estado. A heterogeneidade de ambientes aquáticos locais, forte seleção de habitat aliada à sazonalidade e ausência de outros locais úmidos em seu entorno, explicam a diversidade e distribuição destas aves estreitamente relacionadas aos corpos d'água desta desconhecida ecorregião da Mata Atlântica.

Palavras-chave: áreas úmidas, assembleia de aves, ecologia, heterogeneidade de ambientes.

*e-mail: srposso@hotmail.com

Received: April 23, 2021 - Accepted: August 13, 2021

This is an Open Access article distributed under the terms of the Creative Commons Attribution License, which permits unrestricted use, distribution, and reproduction in any medium, provided the original work is properly cited. 


\section{Introduction}

Protected wetland areas are essential for conserving biodiversity in the face of rapid anthropogenic land use changes and a changing climate (Beatty et al., 2014). The Upper Paraná Forest is an ecoregion of the Atlantic Forest. Although large parts of the forest are still conserved in the southern part, the northwestern part is severely fragmented. This deforestation has occurred due to extensive agriculture, irregular land occupation, dam construction, and unsustainable use of the native forest; this, in turn, has led to illegal hunting. Little is known about the wildlife of this ecoregion because it is located in a poorly accessible area (Rodrigues and Bononi, 2008). According to Silveira and Uezu (2011), the understanding of birdlife in this ecoregion "still has important knowledge gaps and should be the subject of more intense inventories." Indeed, inventories focusing on waterfowl species are of central importance because such birds and their environments require conservation efforts (Donatelli et al., 2014).

Waterfowl are dispersing agents of algae, invertebrates, microorganisms, seeds, pollen, and fish and amphibian eggs (Blanco, 1999). Additionally, they affect both macrophyte and fish biomass, contribute to nutrient cycling, and have high energy requirements; hence, they are sensitive to changes in their habitat conditions (Rodrigues and Michelin, 2005).

This ecoregion experience seasonal flooding. Therefore, studies on the seasonal movements of waterfowls and their spatio-temporal dynamics are crucial for providing the data necessary to plan their conservation (Posso et al., 2012; Donatelli et al., 2014). Nevertheless, very few studies have sought to understand the spatio-temporal dynamics of birds in the Upper Paraná Forest (Zuquim Antas, 1994; Gimenes and Anjos, 2011; Ronchi-Virgolini et al., 2009; Lorenzón et al., 2016, 2019), and none of them has focused on the highly altered northwestern region of the state of São Paulo. Therefore, in this study, we have described the diversity and composition of the aquatic avifauna in this region and analyzed the spatio-temporal similarities among the waterfowl communities of the water bodies in this ecoregion.

\section{Materials and Methods}

\subsection{Study area}

The study was conducted in Reserva Particular do Patrimônio Natural (RPPN) Foz do Rio Aguapeí of Companhia Energética de São Paulo (CESP). It has an area of 9,000 ha and includes Castilho, São João do Pau d'Álho, and Paulicéia municipalities, all of which border the state of Mato Grosso do Sul (see Figure 1). The landscape of the study area consists of a semi-deciduous forest (the forest of Alto Paraná) and includes areas with diverse seasonal flooding. According to Köppen climate classification, the climate of this area is Aw (tropical savanna climate with dry winter characteristics) with two well-defined seasons, namely a dry winter (April to October) and a rainy summer (November to March) (Rocha and Dalponte, 2006). The surroundings of RPPN have been drastically modified by the damming of the Paraná River (Jupiá Hydroelectric Plant) and the extensive deforestation for pastures and sugar cane plantations (CESP, 2013), even though it is located in a priority region with respect to the conservation of inland Atlantic Forest biodiversity (Rodrigues and Bononi, 2008).

\subsection{Data collection}

Data were collected on six occasions during the peaks of drought (June to August, 2012) and rainfall (January to March, 2013) by the same field observers (B. M. Lima and S. R. Posso). Sampling was carried out in the morning (6:00 a.m. to 8:00 a.m.) and afternoon (4:30 p.m. to $6: 30$ p.m.). Six distinct humid areas were

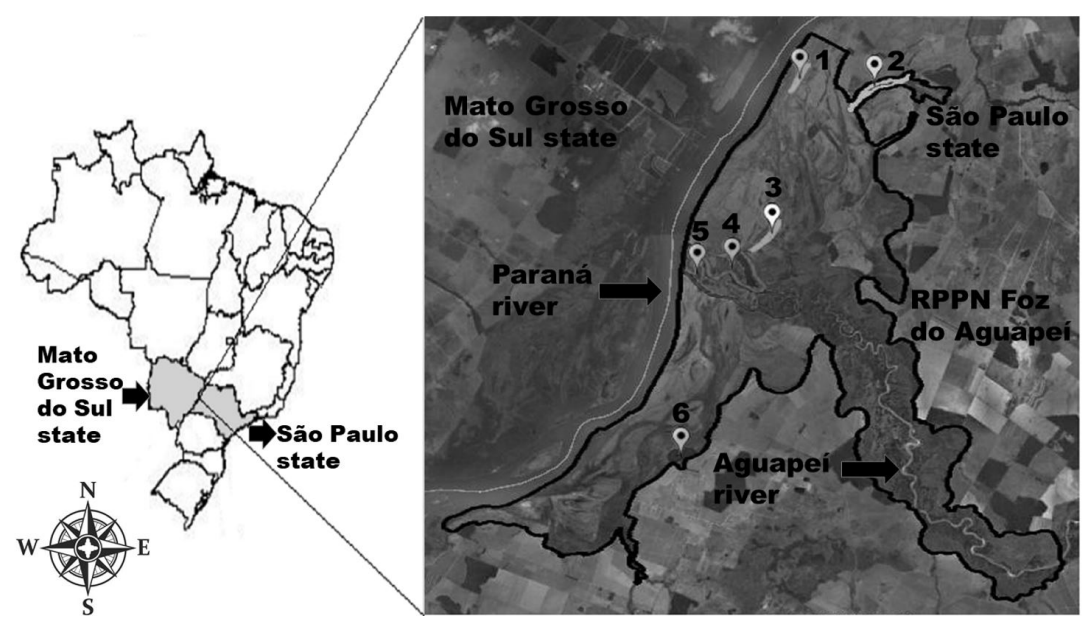

Figure 1. Map of the RPPN Foz do Rio Aguapeí and location of the six studied areas in the RPPN Foz do Rio Aguapeí. Legend: (1) Lagoa São Gabriel; (2) Lagoa das Piranhas; (3) Lagoa dos Porcos; (4) Constructed wetland; (5) Aguapei river -; and (6) Lagoa da sede. Sources: CESP (2013) and Google Earth (2021). 
surveyed (one area per day), one of which was in a lotic environment (Aguapeí River, AR), one in a semi-lotic environment (Constructed Wetland, CW), and four in a lentic environment (Lagoa da Sede, LS; Lagoa São Gabriel, LSG; Lagoa da Piranha, LP; and Lagoa dos Porcos, LPO) (see Figure 1).

The line transect technique was used to observe the birds in predefined trails around the sampling areas (Accordi and Hartz, 2006). We recorded data regarding all the individuals that were spotted as long as they were feeding and swimming/diving within a $20 \mathrm{~m}$ radius from the water body; each individual's record was considered a single contact for data analysis. As birds were not individually marked, to avoid resampling individuals during an observation period, we defined the water body and the direction to be followed to start data collection by randomization. The observer used a Nikon Monarch (8x40) binocular, Tascam DR-05X Professional recorder, and Nikon 3.200 (300 mm lens) camera for observation and subsequent species identification of the birds. Migratory bird species were identified according to Somenzari et al. (2018), and the individual species were characterized, along with the scientific nomenclature, based upon the CBRO list (Pacheco et al., 2021).

\subsection{Data analyses}

Richness and abundance were used as the main descriptors of the avifauna. The rarefaction curve and first-order jackknife richness estimator (Burnham and Overton, 1978) were used to estimate sample efficiency, while abundance was calculated from direct counts (Accordi and Hartz, 2006). The Shannon-Wiener index was used to evaluate the species diversity, and the evenness index was calculated to evaluate sample homogenization. Differences in abundance and richness between the dry and rainy seasons were compared using paired Student's t-test, in which the values of total number of birds as well as total number of waterfowl species from every water body in both the seasons was considered. Before analysis the data were log transformed to improve linearity (Shapiro-Wilk, $\mathrm{W}=0.95, \mathrm{p}=0.74$ [dry season, bird number]; $\mathrm{W}=0.83$, $\mathrm{p}=0.11$ [wet season, bird number]; $\mathrm{W}=0.96, \mathrm{p}=0.82$ [dry season, species number]; $\mathrm{W}=0.94, \mathrm{p}=0.69$ [wet season, species number]), with $\mathrm{p}<0.05$ considered significant.

We used an analysis of similarity (ANOSIM) to test the differences in the composition of the bird species among the various sampling transects of the different habitat types. The ANOSIM procedure used Monte Carlo randomization of the observed data to assess whether the rank similarities within the groups (transects) are greater than the ones among different groups (habitat types). The Bray-Curtis index was used to express similarities, and 10,000 Monte Carlo permutations were conducted to generate a random test statistic. If the ANOSIM was significant, we conducted a non-metric multidimensional scaling (NMDS) ordination; this technique is also based on the Bray-Curtis similarity measure between any two sites. We performed this analysis to further explore the differences in community structure at the transect-level within and among different habitats. The abundance measure used in the ordination is the number of contacts observed at each transect. Transects from a given habitat type were thus positioned in ordination space according to their composition as well as abundance of waterfowl species. We observed a high abundance of species, mostly including individuals of small species that are associated with the riparian vegetation along the lotic areas, around the lotic and semi-lotic areas. Since this could make the ordination non-informative, we separated the lotic (AR) and semi-lotic (CW) water bodies from the lentic ones (LS, LSG, LP, and LPO). All analyses were performed using the PAST software (Hammer et al., 2001).

\section{Results}

Fifty-two species from 22 families and 9 orders were observed, and 1.466 waterfowl contacts were recorded (as shown in Table 1).

The species' richness estimate ("first-order jackknife") was $64.5 \pm 3.9$ species, and the cumulative species curve showed stability from sample 27 to 31 (52 species) (see Figure 2).

Five species with partially migratory behavior were recorded, namely Dendrocygna bicolor (Vieillot, 1816), Platalea ajaja (Linnaeus, 1758), R. sociabilis, Porphyrio martinica (Linnaeus, 1766), and Rynchops niger (Linnaeus, 1758) (as shown in Table 1 ).

The richest family was Ardeidae (nine species, approximately $18 \%$ of the total species), followed by Rallidae (seven species, 14\%), and Anatidae (five species, 10\%). Threskiornithidae, Accipitridae, and Alcedinidae were represented by three species each (6\%). The area with the greatest species richness was the AR ( 35 species), followed by LP (29), CW and LSG (24 each), LPO (23), and LS (17). Only seven species were common to all the six areas, namely C. moschata, T. lineatum, $R$. sociabilis, A. guarauna, $V$. chilensis, J. jacana, and A. leucocephala. Eight species were recorded only in the rainy season, namely Tigrisoma fasciatum (Such, 1825), Phimosus infuscatus (Lichtenstein, 1823), Aramides cajanea (Muller, 1776), Amaurolimnas concolor (Gosse, 1847), Pardirallus maculatus (Boddaert, 1783), Sternula superciliaris (Vieillot, 1819), Crotophaga major (Gmelin, 1788), and Coccycua minuta (Vieillot, 1817). On the contrary, 10 species were unique to the dry season, namely $D$. bicolor, Tachybaptus dominicus (Linnaeus, 1766), Podilymbus podiceps (Linnaeus, 1758), Jabiru mycteria (Lichtenstein, 1819), Egretta thula (Molina, 1782), Pardirallus nigricans (Vieillot, 1819), Gallinula galeata (Lichtenstein, 1818), Porphyriops melanops (Vieillot, 1819), $P$. martinica, and $R$. niger.

The six most abundant species corresponded to approximately $55 \%$ of the total number of contacts ( $n=1.466)$ : . sociabilis (12.3\%),J.jacana (12.2\%), A. guarauna (10.5\%), Ardea cocoi (Linnaeus, 1766; 8.6\%), Anhima cornuta (Linnaeus, 1766; 5.8\%), and Nannopterum brasilianum (Gmelin, 1789; 5\%). There were no significant seasonal differences in either the species composition (Paired t-test, $t=0.78, \mathrm{p}=0.470$ ) or the number of birds observed (Paired t-test, $t=0.75, \mathrm{p}=0.488$ ). The most abundant bird species during the dry and rainy seasons were J. jacana 
Table 1. List and classification of the aquatic bird species recorded in the RPPN Foz do Rio Aguapeí between 2012 and 2013.

\begin{tabular}{|c|c|c|c|c|c|c|c|c|}
\hline Taxa & AR & CW & LS & LSG & LP & LPO & $\begin{array}{c}\text { Total RPPN } \\
(\%) \\
\end{array}$ & NB \\
\hline \multicolumn{9}{|l|}{$\begin{array}{l}\text { Anseriformes Linnaeus, } \\
\qquad 1758\end{array}$} \\
\hline \multicolumn{9}{|l|}{$\begin{array}{c}\text { Anhimidae Stejneger, } \\
1885\end{array}$} \\
\hline $\begin{array}{l}\text { Anhima cornuta } \\
\text { (Linnaeus, 1766) }\end{array}$ & 66 & 15 & - & - & 3 & 2 & $86(5.87 \%)$ & RES \\
\hline \multicolumn{9}{|l|}{ Anatidae Leach, 1820} \\
\hline $\begin{array}{l}\text { Dendrocygna bicolor } \\
\text { (Vieillot, 1816) }\end{array}$ & 17 & - & - & - & - & - & $17(1.16 \%)$ & MIG \\
\hline $\begin{array}{l}\text { Dendrocygna viduata } \\
\text { (Linnaeus, 1766) }\end{array}$ & - & - & - & - & 3 & 2 & $5(0.34 \%)$ & RES \\
\hline $\begin{array}{l}\text { Dendrocygna autumnalis } \\
\quad \text { (Linnaeus, 1758) }\end{array}$ & 6 & - & 7 & - & 8 & - & $21(1.43 \%)$ & RES \\
\hline $\begin{array}{l}\text { Cairina moschata } \\
\text { (Linnaeus, 1758) }\end{array}$ & 6 & 5 & 3 & 2 & 6 & 7 & $29(1.97 \%)$ & RES \\
\hline $\begin{array}{l}\text { Amazonetta brasiliensis } \\
\qquad(\text { Gmelin, 1789) }\end{array}$ & 3 & - & - & - & 10 & - & $13(0.88 \%)$ & RES \\
\hline \multicolumn{9}{|l|}{ Podicipediformes } \\
\hline \multicolumn{9}{|l|}{ Fürbringer, 1888} \\
\hline \multicolumn{9}{|l|}{ Podicipedidae } \\
\hline \multicolumn{9}{|l|}{ Bonaparte, 1831} \\
\hline $\begin{array}{l}\text { Tachybaptus dominicus } \\
\text { (Linnaeus, 1766) }\end{array}$ & - & - & - & - & 1 & - & $1(0.06 \%)$ & RES \\
\hline $\begin{array}{l}\text { Podilymbus podiceps } \\
\text { (Linnaeus, 1758) }\end{array}$ & - & - & - & 2 & - & - & $2(0.13 \%)$ & RES \\
\hline \multicolumn{9}{|l|}{$\begin{array}{c}\text { Cuculiformes Wagler, } \\
1830\end{array}$} \\
\hline \multicolumn{9}{|l|}{ Cuculidae Leach, 1820} \\
\hline $\begin{array}{c}\text { Crotophaga major Gmelin, } \\
1788\end{array}$ & 51 & 8 & - & 2 & - & - & $61(4.16 \%)$ & RES \\
\hline $\begin{array}{c}\text { Coсcyсua minuta } \\
\text { (Vieillot, 1817) }\end{array}$ & 1 & - & - & - & - & - & $1(0.06 \%)$ & RES \\
\hline \multicolumn{9}{|l|}{$\begin{array}{c}\text { Gruiformes Bonaparte, } \\
1854\end{array}$} \\
\hline \multicolumn{9}{|l|}{$\begin{array}{c}\text { Aramidae Bonaparte, } \\
1852\end{array}$} \\
\hline $\begin{array}{c}\text { Aramus guarauna } \\
\text { (Linnaeus, 1766) }\end{array}$ & 45 & 52 & 9 & 26 & 14 & 9 & $155(10.58 \%)$ & RES \\
\hline \multicolumn{9}{|l|}{$\begin{array}{c}\text { Rallidae Rafinesque, } \\
1815\end{array}$} \\
\hline $\begin{array}{l}\text { Porphyriops melanops } \\
\text { (Vieillot, 1819) }\end{array}$ & - & - & - & 1 & - & - & $1(0.06 \%)$ & RES \\
\hline $\begin{array}{l}\text { Porphyrio martinicus } \\
\text { (Linnaeus, 1766) }\end{array}$ & - & - & - & 1 & - & 2 & $3(0.20 \%)$ & MIG \\
\hline $\begin{array}{l}\text { Aramides cajaneus } \\
\text { (Statius Muller, 1776) }\end{array}$ & 1 & - & - & - & - & - & $1(0.06 \%)$ & RES \\
\hline $\begin{array}{l}\text { Amaurolimnas concolor } \\
\text { (Gosse, 1847) }\end{array}$ & - & - & - & - & - & 1 & $1(0.06 \%)$ & RES \\
\hline $\begin{array}{l}\text { Pardirallus maculatus } \\
\text { (Boddaert, 1783) }\end{array}$ & - & - & - & - & 1 & - & $1(0.06 \%)$ & RES \\
\hline $\begin{array}{l}\text { Pardirallus nigricans } \\
\text { (Vieillot, 1819) }\end{array}$ & - & - & - & 1 & 1 & - & $2(0.13 \%)$ & RES \\
\hline $\begin{array}{l}\text { Gallinula galeata } \\
\text { (Lichtenstein, 1818) }\end{array}$ & - & - & - & - & - & 1 & $1(0.06 \%)$ & RES \\
\hline \multicolumn{9}{|l|}{$\begin{array}{c}\text { Charadriiformes Huxley, } \\
1867\end{array}$} \\
\hline $\begin{array}{c}\text { Charadriidae Leach, } \\
1820\end{array}$ & & & & & & & & \\
\hline
\end{tabular}

Legend: (AR) Aguapeí River; (CW) Constructed Wetland; (LS) Lagoa da Sede; (LSG) Lagoa São Gabriel; (LP) Lagoa da Piranha; (LPO) Lagoa dos Porcos = Species abundance in the aquatic environment. Total species abundance and percentage in the RPPN Foz do Rio Aguapeí. NB (Nomadic Behavior) = RES (Resident); MIG (Migrant). 
Table 1. Continued..

\begin{tabular}{|c|c|c|c|c|c|c|c|c|}
\hline Taxa & AR & CW & LS & LSG & LP & LPO & $\begin{array}{c}\text { Total RPPN } \\
(\%) \\
\end{array}$ & NB \\
\hline $\begin{array}{l}\text { Vanellus chilensis } \\
\text { (Molina, 1782) }\end{array}$ & 21 & 9 & 2 & 18 & 26 & 3 & $79(5.39 \%)$ & RES \\
\hline $\begin{array}{l}\text { Himantopus melanurus } \\
\text { Vieillot, } 1817\end{array}$ & 1 & - & - & - & - & - & $1(0.06 \%)$ & RES \\
\hline \multicolumn{9}{|l|}{$\begin{array}{c}\text { Jacanidae Chenu \& Des } \\
\text { Murs, } 1854\end{array}$} \\
\hline $\begin{array}{c}\text { Jacana jacana } \\
\text { (Linnaeus, 1766) }\end{array}$ & 13 & 47 & 9 & 55 & 31 & 25 & $180(12.28 \%)$ & RES \\
\hline \multicolumn{9}{|l|}{ Laridae Rafinesque, 1815} \\
\hline $\begin{array}{c}\text { Rynchops niger Linnaeus, } \\
1758\end{array}$ & 1 & - & - & - & - & - & $1(0.06 \%)$ & MIG \\
\hline $\begin{array}{l}\text { Sternula superciliaris } \\
\text { (Vieillot, 1819) }\end{array}$ & - & 4 & - & - & 1 & - & $5(0.34 \%)$ & RES \\
\hline $\begin{array}{l}\text { Phaetusa simplex } \\
\text { (Gmelin, 1789) }\end{array}$ & 4 & 4 & - & - & 2 & - & $10(0.68 \%)$ & RES \\
\hline \multicolumn{9}{|l|}{ Ciconiiformes } \\
\hline \multicolumn{9}{|l|}{$\begin{array}{c}\text { Ciconiidae Sundevall, } \\
1836\end{array}$} \\
\hline $\begin{array}{c}\text { Jabiru mycteria } \\
\text { (Lichtenstein, 1819) }\end{array}$ & - & - & - & 1 & - & - & $1(0.06 \%)$ & RES \\
\hline $\begin{array}{l}\text { Mycteria americana } \\
\text { Linnaeus, } 1758\end{array}$ & 2 & 2 & - & 1 & - & - & $5(0.34 \%)$ & RES \\
\hline \multicolumn{9}{|l|}{ Anhingidae } \\
\hline $\begin{array}{l}\text { Anhinga anhinga } \\
\text { (Linnaeus, 1766) }\end{array}$ & 14 & 2 & 2 & 2 & 3 & - & $23(1.56 \%)$ & RES \\
\hline \multicolumn{9}{|l|}{ Phalacrocoracidae } \\
\hline $\begin{array}{l}\text { Nannopterum brasilianum } \\
\quad(\text { Gmelin, 1789) }\end{array}$ & 48 & 15 & 4 & 2 & 5 & - & $74(5.05 \%)$ & RES \\
\hline \multicolumn{9}{|l|}{$\begin{array}{c}\text { Pelecaniformes Sharpe, } \\
1891\end{array}$} \\
\hline \multicolumn{9}{|l|}{ Ardeidae Leach, 1820} \\
\hline $\begin{array}{l}\text { Tigrisoma lineatum } \\
\text { (Boddaert, 1783) }\end{array}$ & 1 & 12 & 2 & 9 & 17 & 3 & $44(3.0 \%)$ & RES \\
\hline $\begin{array}{l}\text { Tigrisoma fasciatum } \\
\quad \text { (Such, 1825) }\end{array}$ & - & - & - & 1 & - & - & $1(0.06 \%)$ & RES \\
\hline $\begin{array}{l}\text { Nycticorax nycticorax } \\
\text { (Linnaeus, 1758) }\end{array}$ & 4 & 2 & - & 47 & 2 & 1 & $56(3.82 \%)$ & RES \\
\hline $\begin{array}{l}\text { Butorides striata } \\
\text { (Linnaeus, 1758) }\end{array}$ & 41 & 3 & - & 6 & - & 5 & $55(3.75 \%)$ & RES \\
\hline $\begin{array}{c}\text { Bubulcus ibis } \\
\text { (Linnaeus, 1758) }\end{array}$ & - & - & - & - & 4 & - & $4(0.27 \%)$ & RES \\
\hline $\begin{array}{c}\text { Ardea cocoi Linnaeus, } \\
1766\end{array}$ & 60 & 37 & - & 8 & 14 & 7 & $126(8.60 \%)$ & RES \\
\hline Ardea alba Linnaeus, 1758 & - & 13 & 8 & 5 & 7 & 4 & $37(2.52 \%)$ & RES \\
\hline $\begin{array}{c}\text { Syrigma sibilatrix } \\
\text { (Temminck, 1824) }\end{array}$ & - & 2 & 2 & - & 1 & - & $5(0.34 \%)$ & RES \\
\hline Egretta thula (Molina, 1782) & 3 & - & - & - & 1 & - & $4(0.27 \%)$ & RES \\
\hline \multicolumn{9}{|l|}{$\begin{array}{l}\text { Threskiornithidae } \\
\text { Poche, } 1904\end{array}$} \\
\hline $\begin{array}{l}\text { Phimosus infuscatus } \\
\text { (Lichtenstein, 1823) }\end{array}$ & - & 1 & - & - & - & - & $1(0.06 \%)$ & RES \\
\hline $\begin{array}{l}\text { Theristicus caudatus } \\
\text { (Boddaert, 1783) }\end{array}$ & - & - & 2 & 2 & 14 & 1 & $19(1.29 \%)$ & RES \\
\hline $\begin{array}{l}\text { Platalea ajaja Linnaeus, } \\
1758\end{array}$ & - & - & - & - & 1 & - & $1(0.06 \%)$ & MIG \\
\hline
\end{tabular}

Legend: (AR) Aguapeí River; (CW) Constructed Wetland; (LS) Lagoa da Sede; (LSG) Lagoa São Gabriel; (LP) Lagoa da Piranha; (LPO) Lagoa dos Porcos = Species abundance in the aquatic environment. Total species abundance and percentage in the RPPN Foz do Rio Aguapeí. NB (Nomadic Behavior) = RES (Resident); MIG (Migrant). 
Table 1. Continued..

\begin{tabular}{|c|c|c|c|c|c|c|c|c|}
\hline Taxa & AR & CW & LS & LSG & LP & LPO & $\begin{array}{c}\text { Total RPPN } \\
(\%)\end{array}$ & NB \\
\hline \multicolumn{9}{|l|}{$\begin{array}{c}\text { Accipitridae Vigors, } \\
1824\end{array}$} \\
\hline $\begin{array}{c}\text { Circus buffoni } \\
\text { (Gmelin, 1788) }\end{array}$ & 8 & - & 1 & 2 & 1 & 1 & $13(0.88 \%)$ & RES \\
\hline $\begin{array}{l}\text { Busarellus nigricollis } \\
\text { (Latham, 1790) }\end{array}$ & 6 & - & - & - & - & 2 & $8(0.54 \%)$ & RES \\
\hline $\begin{array}{l}\text { Rosthramus sociabilis } \\
\text { (Vieillot, 1817) }\end{array}$ & 53 & 68 & 23 & 6 & 12 & 19 & $181(12.3 \%)$ & MIG \\
\hline \multicolumn{9}{|l|}{$\begin{array}{c}\text { Coraciiformes Forbes, } \\
1844\end{array}$} \\
\hline \multicolumn{9}{|l|}{$\begin{array}{c}\text { Alcedinidae Rafinesque, } \\
1815\end{array}$} \\
\hline $\begin{array}{l}\text { Megaceryle torquata } \\
\text { (Linnaeus, 1766) }\end{array}$ & 6 & 1 & 3 & - & 1 & 2 & $13(0.88 \%)$ & RES \\
\hline $\begin{array}{l}\text { Chloroceryle amazona } \\
\text { (Latham, 1790) }\end{array}$ & 5 & 2 & 6 & - & 1 & 1 & $15(1.02 \%)$ & RES \\
\hline $\begin{array}{l}\text { Chloroceryle americana } \\
\text { (Gmelin, 1788) }\end{array}$ & 4 & 1 & - & - & - & - & $5(0.34 \%)$ & RES \\
\hline \multicolumn{9}{|l|}{$\begin{array}{c}\text { Passeriformes Linnaeus, } \\
1758\end{array}$} \\
\hline \multicolumn{9}{|l|}{ Tyrannidae Vigors, 1825} \\
\hline $\begin{array}{l}\text { Fluvicola nengeta } \\
\text { (Linnaeus, 1766) }\end{array}$ & 6 & - & 2 & 1 & - & - & $9(0.61 \%)$ & RES \\
\hline $\begin{array}{l}\text { Arundinicola leucocephala } \\
\text { (Linnaeus, 1764) }\end{array}$ & 1 & 2 & 8 & 1 & 6 & 3 & $21(1.43 \%)$ & RES \\
\hline \multicolumn{9}{|l|}{$\begin{array}{l}\text { Donacobiidae Aleixo \& } \\
\text { Pacheco, } 2006\end{array}$} \\
\hline $\begin{array}{l}\text { Donacobius atricapilla } \\
\quad \text { (Linnaeus, 1766) }\end{array}$ & 2 & - & - & - & - & 3 & $5(0.34 \%)$ & RES \\
\hline \multicolumn{9}{|l|}{ Icteridae Vigors, 1825} \\
\hline $\begin{array}{c}\text { Amblyramphus } \\
\text { holosericeus } \\
\text { (Scopoli, 1786) }\end{array}$ & 3 & - & - & - & - & - & $3(0.20 \%)$ & RES \\
\hline $\begin{array}{l}\text { Leistes superciliaris } \\
\text { (Bonaparte, 1850) }\end{array}$ & 2 & - & - & - & - & 1 & $3(0.20 \%)$ & RES \\
\hline \multicolumn{9}{|l|}{$\begin{array}{c}\text { Thraupidae Cabanis, } \\
\qquad 1847\end{array}$} \\
\hline $\begin{array}{c}\text { Paroaria capitata } \\
\text { (d'Orbigny } \\
\text { \& Lafresnaye, 1837) }\end{array}$ & 49 & 8 & - & - & - & - & $57(3.89 \%)$ & RES \\
\hline
\end{tabular}

Legend: (AR) Aguapeí River; (CW) Constructed Wetland; (LS) Lagoa da Sede; (LSG) Lagoa São Gabriel; (LP) Lagoa da Piranha; (LPO) Lagoa dos Porcos = Species abundance in the aquatic environment. Total species abundance and percentage in the RPPN Foz do Rio Aguapeí. NB (Nomadic Behavior) = RES (Resident); MIG (Migrant).

(110 contacts) and $R$. sociabilis (101 contacts), respectively. The AR had the highest bird abundance (554 contacts) followed by CW (315), LSG (202), LP (197), LPO (105), and LS (93). In the AR, A. cornuta was the most abundant (66 contacts), and in both CW and LS, $R$. sociabilis was the most abundant (68 and 23, respectively). Jacana jacana was the most abundant in LSG, LP, and LPO $(55,31$, and 25 , respectively).

The Shanon-Wiener diversity index for the total area was 3.121, whereas for each habitat type, it was 2.27 (LSG), 2.466 (CW), 2.492 (LS), 2.586 (LPO), 2.841 (LP), and 2.867 (AR).
In terms of seasonality, the differences in the composition of the bird species were higher between the lotic and lentic habitats than within individual habitat type (ANOSIM, $\mathrm{r}=0.69, \mathrm{p}<0.047$ ). This result reflected the coherence of the dispersion of water bodies in the ordering diagram according to the composition of bird species in each habitat type across seasons. Some of the waterfowl species were restricted to a certain type of habitat in a given season, whereas some of the habitats shared different complements of their avifauna with other locations (as shown in Table 1). The major contrast in species composition was between the bird assemblages 


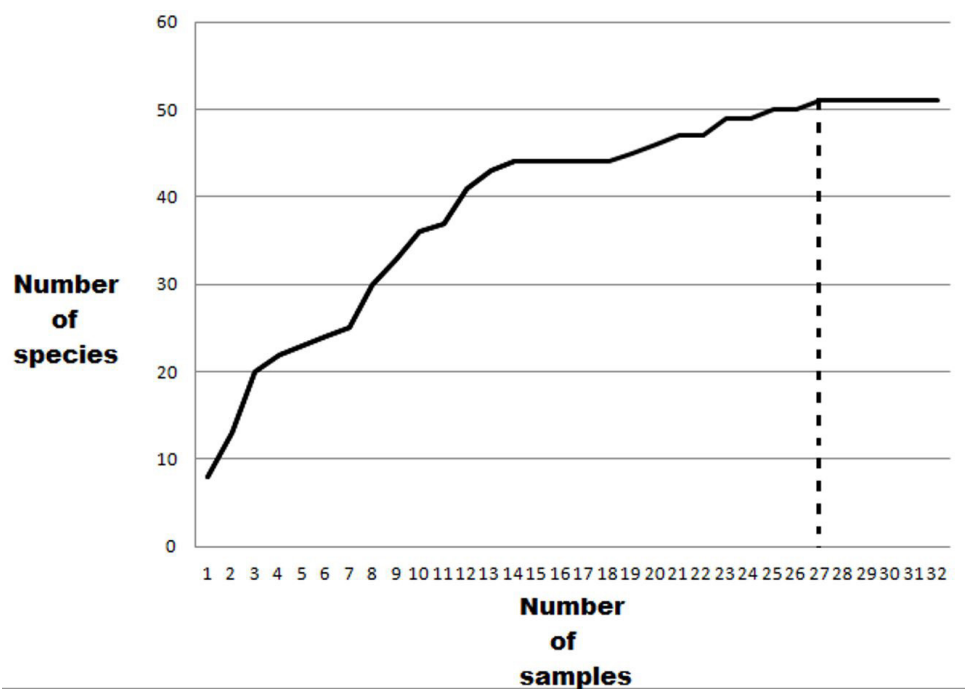

Figure 2. Cumulative curve of the 52 waterfowl bird species in the RPPN Foz do Rio Aguapeí showing stability from sample 27 to 31.

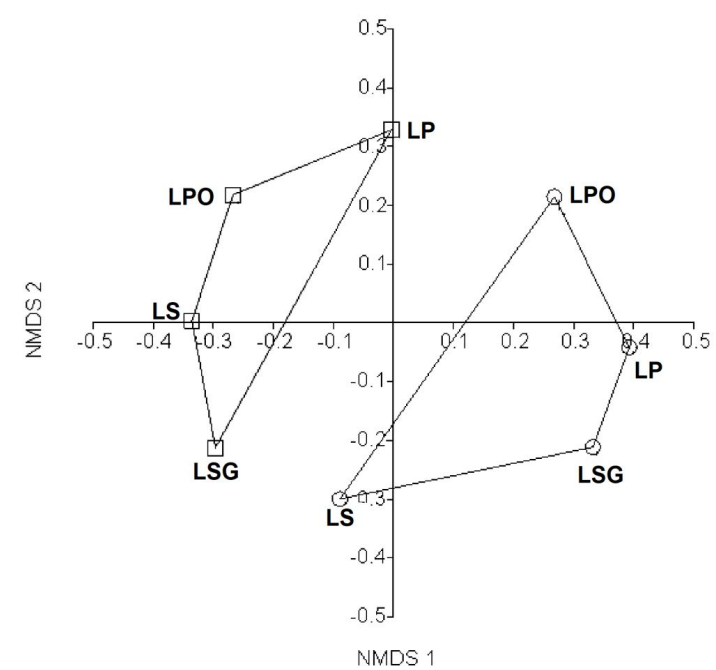

Figure 3. NMDS (stress of 0.097) of the spatial distribution of the aquatic bird community recorded by the transect method in the lagoons of the RPPN Foz do Aguapeí, during the dry (rounded symbols) and rainy seasons (square symbols). Legend: LS = Lagoa da Sede; LSG = Lagoa São Gabriel; LP = Lagoa da Piranha and LPO = Lagoa dos Porcos.

of LP (the longest lagoon with riparian vegetation) in the dry season and LS (the smallest lagoon without riparian vegetation) during the rainy season. These observations were supported by the NMDS order (stress $=0.097$; see Figure 3 ) and by axis 1 , where these assemblies diverged considerably in their bird composition. Moreover, there was a marked dissimilarity among the bird assemblages of the different habitats in the different seasons; the bird assemblages of $\mathrm{CW}$ and $\mathrm{AR}$ occupied the opposite ends of the dispersion diagram in each season (NMDS, stress $=0.001$; see Figure 4 ). Therefore, it is important to note

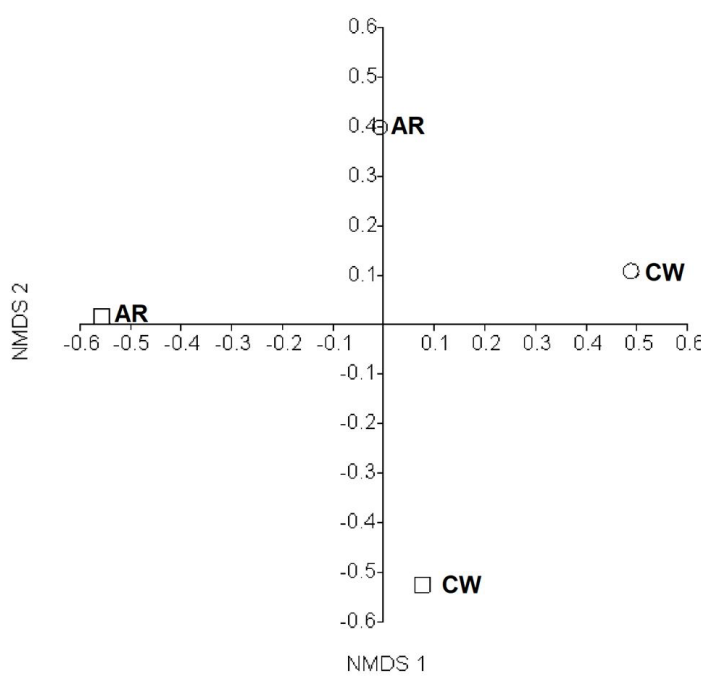

Figure 4. NMDS (stress of 0.001) of the spatial distribution of the aquatic bird community recorded by the transect method in the lotic environments of the RPPN Foz do Aguapeí, during the dry (rounded symbols) and rainy seasons (square symbols). Legend: $\mathrm{AR}=$ Aguapeí River and CW = Constructed wetland.

that each of these habitats was dissimilar in terms of bird assembly in each season (as shown in Table 1, see Figure 4).

\section{Discussion}

The richness of aquatic birds in the total study area in our study was lower than that reported in similar neotropical studies, such as Accordi and Hartz (2006; $\mathrm{n}=210$ species), Ronchi-Virgolini et al. (2009; $\mathrm{n}=129$ ), Donatelli et al. (2014; $n$ = 135), and Lorenzón et al. $(2016,2019 ; n$ = 162). 
This might be because individuals of the bird species flying over humid areas (mainly the birds of Hirundinidae, Apodidae, and Tyrannidae) were not recorded in the present study. Nevertheless, this study demonstrated how little is known about the bird wildlife in the northwest region of the state of São Paulo. Bispo et al. (2012) had reported 328 species of birds from the Alto Parana Atlantic Forest (these authors had included birds flying over humid areas). Despite that, our study included 11 bird species that were not a part of their list, namely $T$. fasciatum, P. infuscatus, A. concolor, Circus buffoni (Gmelin, 1788), P. maculatus, P. nigricans, $P$. melanops, S. superciliaris, $R$. niger, C. minuta, and Amblyramphus holosericeus (Scopoli, 1786).

The analysis of species richness and the accumulation curve indicated that the sampling was adequate. Only seven waterfowl species were common to all the humid areas; this might indicate habitat selection according to the following criteria: a) the studied species are residents in the reserve, and they also show local dispersions, especially at short/medium distances among the different aquatic environments of the reserve; $b$ ) the studied species concentrate in low densities in areas with few resources; c) the studied species coexist with other species that use similar resources; and d) the studied species exhibit high adaptability with respect to the use of resources (Snyder and Chesson, 2003; Figueira et al., 2006; Accordi and Hartz, 2006; Beatty et al., 2014).

The regularity in the abundance of certain waterfowls in our records (R. sociabilis, J. jacana, A. guarauna, A. cocoi, and $N$. brasilianum ) presumably resulted from their resident behavior in the aquatic environments that had a constant availability of food as well as their significant flexibility for displacement (Gimenes and Anjos, 2011). For example, J. jacana is observed to be moving around water hyacinths and other floating plants as well as among the aquatic sampling areas in search of food, especially during its non-reproductive period (Sick, 2001). Its population increases in the dry season; this might be associated with the development of aquatic vegetation on the margins and in the interior parts of the habitats that provide newer spots for foraging.

During the dry season, we recorded 10 bird species that were not detected during the rainy season; moreover, we registered 8 species that were exclusive to the rainy season. The decrease in the water level during the droughts favors the formation of microhabitats suitable for the foraging of those species that explore moist margins and shallow waters (Donatelli et al., 2014). The most abundant species in the drought period were $D$. bicolor, Nycticorax nycticorax (Linnaeus, 1758), Ardea alba (Linnaeus, 1758), and V. chilensis. During the rainy season, the waterfowl species that feed on lush vegetation become abundant; on the contrary, during the dry season, there is a rich abundance of those waterfowl species that can capture food in shallow waters (Accordi and Hartz, 2006; Figueira et al., 2006; Gimenes and Anjos, 2011; Donatelli et al., 2014). These authors claim that during the dry season, there is a scarcity of resources, and this promotes a greater concentration of the waterfowls in the humid areas; this, in turn, leads to the population increase of the waterfowls. However, we noticed that some species, namely $R$. sociabilis, $C$. major,
Donacobius atricapilla (Linnaeus, 1766), Fluvicola nengeta (Linnaeus, 1766), A. leucocephala, and Paroaria capitata (d'Orbigny and Lafresnaye, 1837), had a higher abundance in the rainy season than in the dry season; this, in turn, led to a non-significant difference in their relative abundances between the two seasons. Pereira (2010) reported that with an increase in the water level (during the rainy season), insect abundance increases in the water as well as in the floating vegetation; this can explain the increase in the abundance of insectivorous birds, such as $D$. atricapilla, $F$. nengeta, A. leucocephala, and $P$. capitata, in the rainy season.

Our analyses showed pronounced seasonal differences in the species richness as well as the abundance of waterfowls in similar areas. Such variations are probably closely associated with the dissimilarities in the bird assemblages recorded between the two seasons in these areas. Furthermore, the richness of aquatic birds may also be influenced by variations in the particular flora of each habitat, which indicates that species distribution is influenced not only by seasonal variation, but also by habitat selection (Anderson et al., 1983; Donatelli et al., 2014; Beatty et al., 2014). The four studied ponds were similar to each other in terms of the waterfowl assembly as all of them were shallow and had distinct aquatic vegetation and macrophytes, such as Brachiaria subquadripara (Trin.) Hitchcock, Eichhornia azurea Kunth., Eichhornia crassipes (Mart.) Solms, Eleocharis elegans (Kunth) Roem. \& Schult, and Panicum repens L. (CESP, 2013). The AR and CW, which are lotic environments, present a riparian forest of arboreal size on its margins, marginal lagoons, and sand banks forming small beaches; these habitats attract specific bird species. Theoretically, such habitat types are adequate for the diverse bird species to capture fish (Gimenes and Anjos, 2011). Wading piscivorous birds, such as ardeids, were abundantly spotted during the entire study period, particularly in the shallow lagoons formed on the banks of lotic water bodies. Apparently, the ability of the kingfishers to perch along the marginal vegetation and dive to ambush their prey has led to their increased presence in these lotic environments (Sick, 2001).

Some studies have detected marked seasonal differences in the richness of the waterfowl species, indicating a strong adaptation to the changes in the dry and rainy seasons, particularly the variations in the water level, which consequently alter the availability of food (Gimenes and Anjos, 2011; Donatelli et al., 2014). Certain species of waterfowl perform migrations in response to these variations; for example, migratory waterfowl species, such as $D$. bicolor, $P$. martinica, and $R$. niger can be observed more frequently in the dry season than in the rainy season as they use these humid areas for feeding during this dry period (Accordi and Hartz, 2006; Donatelli et al., 2014). Such regional migrations increase the differences in the composition of avifauna between the two seasons. Therefore, these data suggest that the composition of local waterfowl species not only fluctuates over time (due to annual fluctuation in the water levels), but also over space (specificities of wetlands), reinforcing habitat selection and corroborating the results of a previous study on waterfowl in the Alto Paraná (Ronchi-Virgolini et al., 2009). 
The Upper Paraná Atlantic Forest is an environment with a variety of niches and resources that allows the existence of several species; this is evident from the heterogeneity of the sampled locations. The heterogeneity of the environment provides areas of high structural diversity, thereby offering places for feeding, hiding, roosting, and nesting of the waterfowls (Lorenzón et al., 2016, 2019). This highlights the importance of conservation of this area with respect to the maintenance of these waterfowl populations, which is approximately $1 / 3$ of all the freshwater aquatic birds in the entire state of São Paulo (Silveira and Uezu, 2011). Furthermore, it should be noted that 5 migratory species (Somenzari et al., 2018) and 11 bird species that are yet to be registered in the northwestern part of the state (Bispo et al., 2012) were recorded during this study (as shown in Table 1).

Finally, our data confirmed that the total studied area is an outstanding refuge for waterfowl, even though its surroundings have been completely altered by the damming of the Paraná River and the development of agribusiness (CESP, 2013). Therefore, appropriate protection and conservation measures must be adopted for this reserve, particularly in the degraded and little-known ecoregion of the Atlantic Forest, to maintain this significantly diverse population of aquatic birds.

\section{Acknowledgements}

We thank the Companhia Energética de São Paulo (CESP), particularly Messrs. Dimas and Pastana, for allowing and hosting B.M. Lima and S.R. Posso in the study area, PPG Biologia Animal at UFMS (Master degree of the B.M. Lima), and the anonymous reviewers for contributing to and improving the quality of this article.

\section{References}

ACCORDI, I.A. and HARTZ, S.M., 2006. Distribuição espacial e sazonal da avifauna em uma área úmida costeira do sul do Brasil. Revista Brasileira de Ornitologia, vol. 14, no. 2, pp. 117-135.

ANDERSON, B.W., OHMART, R.D. and RICE, J., 1983. Avian and vegetation community structure and this seasonal relationship in the lower Colorado river valley. The Condor, vol. 85, no. 4 , pp. 392-405. http://dx.doi.org/10.2307/1367978.

BEATTY, W.S., KESLER, D.C., WEBB, E.B., RAEDEKE, A.H., NAYLOR, L.W. and HUMBURG, D.D., 2014. The role of protected area wetlands in waterfowl habitat conservation: implications for protected area network design. Biological Conservation, vol. 176, no. 1, pp. 144-152. http://dx.doi.org/10.1016/j.biocon.2014.05.018.

BISPO, A.A., HASUI, E. and PEDRO, W.A. 2012. Aves da região noroeste do estado de São Paulo. In: O. NECCHI, ed. Fauna e flora de fragmentos florestais remanescentes da região nordeste do estado de São Paulo. São Paulo: Holos Editora, pp. 242-268.

BLANCO, D.E. 1999. Los humedales como habitat de aves acuaticas. In: A.I. MALVÁREZ, ed. Tópicos sobre humedales subtropicales $y$ templados en Sudamérica. Montevideo: Orcyt-Unesco, pp. 208-217.

BURNHAM, K.P. and OVERTON, W.S., 1978. Estimation of the size of a closed population when capture probabilities vary among animals. Biometrika, vol. 65, no. 3, pp. 625-633. http://dx.doi. org/10.1093/biomet/65.3.625.

COMPANHIA ENERGÉTICA DE SÃO PAULO - CESP, 2013. Roteiro para elaboração do Plano de Manejo para a RPPN Foz do Aguapeí. São Paulo: CESP, 479 p.

DONATELLI, R.J., POSSO, S.R. and TOLEDO, M.C.B., 2014. Distribution, composition and seasonality of aquatic birds in the Nhecolândia sub-region of South Pantanal, Brazil. Brazilian Journal of Biology = Revista Brasileira de Biologia, vol. 74, no. 4, pp. 844-853. http:// dx.doi.org/10.1590/1519-6984.05013. PMid:25627594.

FIGUEIRA, J.E.C., CINTRA, R., VIANA, L.R. and YAMASHITA, C., 2006. Spatial and temporal patterns of bird species diversity in the Pantanal of Mato Grosso, Brazil: implications for conservation. Brazilian Journal of Biology = Revista Brasileira de Biologia, vol. 66, no. 2A, pp. 393-404. http://dx.doi.org/10.1590/S151969842006000300003. PMid:16862292.

GIMENES, M.R. and ANJOS, L., 2011. Quantitative Analysis of Foraging Habitat Use by Ciconiiformes in the Upper Paraná River Floodplain, Brazil. Brazilian Archives of Biology and Technology, vol. 54, no. 2, pp. 415-427. http://dx.doi.org/10.1590/S151689132011000200025

GOOGLE EARTH [online], 2021 [viewed 21 July 2021]. Available from: https://www.google.com.br/

HAMMER, O., HARPER, D.A.T. and RYAN, P.D., 2001 [viewed 23 April 2021]. PAST: paleontological Statistics software package for education and data analysis. Palaeontologia Electronica [online], vol. 4, no. 1, pp.1-9. Available from: https://palaeo-electronica. org/2001_1/past/issue1_01.htm

LORENZÓN, R.E., BELTZER, A.H., OLGUIN, P.F. and RONCHI VIRGOLINI, A.L., 2016. Habitat heterogeneity drives bird species richness, nestedness and habitat selection by individual species in fluvial wetlands of the Paraná River, Argentina. Austral Ecology, vol. 41, no. 7, pp. 829-841. http://dx.doi.org/10.1111/aec.12375.

LORENZÓN, R.E., BELTZER, A.H., OLGUIN, P.F., LEÓN, E.J., SOVRANO, L.V., ANTONIAZZI, C.E. and RONCHI VIRGOLINI, A.L., 2019. Temporal variation of regional bird assemblages in highly dynamic fluvial wetlands: seasonality and influence of water level and habitat availability. Revista de Biología Tropical, vol. 67, no. 6, pp. 1131-1145. http://dx.doi.org/10.15517/rbt.v67i6.36734.

PACHECO, J.F., SILVEIRA, L.F., ALEIXO, A., AGNE, C.E., BENCKE, G.A., BRAVO, G.A., BRITO, G.R.R., COHN-HAFT, M., MAURÍCIO, G.N., NAKA, L.N., OLMOS, F., POSSO, S.R., LEES, A.C., FIGUEIREDO, L.F.A., CARRANO, E., GUEDES, R.C., CESARI, E., FRANZ, I., SCHUNCK, F. and DE Q. PIACENTINI, V., 2021. Annotated checklist of the birds of Brazil by the Brazilian Ornithological Records Committee. Ornithology Research, vol. 29, no. 1, pp. 94-105. http://dx.doi. org/10.1007/s43388-021-00058-x.

PEREIRA, G.A., 2010 [viewed 23 April 2021]. Avifauna associada a três lagoas temporárias no estado do Rio Grande do Norte, Brasil. Atualidades Ornitológicas Online [online], vol. 156, no. 1, pp. 5360. Available from: http://ao.com.br/download/A0156_53.pdf

POSSO, S.R., CINTRA, F.B. and FRIAS, J., 2012. Temporal influence on foraging strategies, territoriality and nomadic tendencies of Snail Kite, Rosthramus sociabilis (Viellot, 1817) in an urban Neotropical wetland. Brazilian Journal of Biology $=$ Revista Brasileira de Biologia, vol. 72, no. 2, pp. 235-241. http://dx.doi. org/10.1590/S1519-69842012000200002. PMid:22735129.

ROCHA, E.C. and DALPONTE, J.C., 2006. Composição e caracterização da fauna de mamíferos de médio e grande porte em uma pequena reserva de cerrado em Mato Grosso, Brasil. Revista Árvore, vol. 30, no. 4, pp. 669-677. http://dx.doi.org/10.1590/ S0100-67622006000400021. 
RODRIGUES, M. and MICHELIN, V.B., 2005. Riqueza e diversidade de aves aquáticas de uma lagoa natural no sudeste do Brasil. Revista Brasileira de Zoologia, vol. 22, no. 4, pp. 928-935. http:// dx.doi.org/10.1590/S0101-81752005000400019.

RODRIGUES, R.R. and BONONI, V.L.R., 2008. Diretrizes para conservação e restauração da biodiversidade no estado de São Paulo. São Paulo: Instituto de Botânica, Editora Fapesp, 248 p.

RONCHI-VIRGOLINI, A.L., BELTZER, A.H. and MANZANO, A.S., 2009 Bird communities in wetlands along the Lower Paraná River Entre Ríos, Argentina. Avian Biology Research, vol. 1, no. 4, pp. 153-163. http://dx.doi.org/10.3184/175815508X404282.

SICK, H., 2001. Ornitologia brasileira. São Paulo: Nova Fronteira, 912 p.

SILVEIRA, L.F. and UEZU, A., 2011. Checklist das aves do Estado de São Paulo, Brasil. Biota Neotropical Online, vol. 11, no. 1, suppl. 1, pp. 83-110. http://dx.doi.org/10.1590/S167606032011000500006
SNYDER, R.E. and CHESSON, P., 2003. Local dispersal can facilitate coexistence in the presence of permanent spatial heterogeneity. Ecology Letters, vol. 6, no. 4, pp. 301-309. http://dx.doi. org/10.1046/j.1461-0248.2003.00434.x.

SOMENZARI, M., AMARAL, P.P., CUETO, V.R., GUARALDO, A.C., JAHN, A.E., LIMA, D.M., LIMA, P.C., LUGARINI, C., MACHADO, C.G., MARTINEZ, J., NASCIMENTO, J.L.X., PACHECO, J.F., PALUDO, D., PRESTES, N.P., SERAFINI, P.P., SILVEIRA, L.F., SOUSA, A.E.B.A., SOUSA, N.A., SOUZA, M.A., TELINO-JÚNIOR, W.R. and WHITNEY, B.M., 2018. An overview of migratory birds in Brazil. Papéis Avulsos de Zoologia, vol. 58, no. 1, pp. 3-66. http://dx.doi. org/10.11606/1807-0205/2018.58.03.

ZUQUIM ANTAS, P.T.Z., 1994. Migration and other movements among the lower Paraná River valley wetlands, Argentina, and the south Brazil/Pantanal wetlands. Bird Conservation International, vol. 4, no. 2-3, pp. 181-190. http://dx.doi. org/10.1017/S0959270900002768. 